\title{
STRATEGI PEMASARAN PAKET WISATA PILGRIM PT. DONGAN SAHUTA TOUR AND TRAVEL DI BALI
}

\author{
Paradita Putri Amelia \\ Ni Made Oka Karini \\ Ni Gusti Ayu Susrami Dewi \\ Email : parditamelia@gmail.com \\ PS. S1 Industri Perjalanan Wisata \\ Fakultas Pariwisata UNUD
}

\begin{abstract}
This study aimed to determine the marketing activities of pilgrim package tour that have been performed by PT. Dongan Sahuta Tour and Travel, develop strategies and also marketing programs that can be implemented by the company. Data collection by observation, interviews, questionnaires and literature study. The sampling technique used purposive sampling. Data were analyzed using qualitative descriptive analysis, analysis of the Likert scale and SWOT analysis approach. The results obtained there are four teen indicators of strengths, weaknesses of tree indicators, four indicators of opportunities and four indicators threats. Marketing strategies that can be implemented by the firm such as 1)create and develop a quality product, 2)provide rebates to customers who have used the services of PT. Dongan Sahuta Tour and Travel several times. The advice given are more active in the promotion by giving rebates, conduct marketing activities as E-commers, expand cooperation with business trips or individuals.
\end{abstract}

\section{Keywords: Marketing Environment, Marketing Strategy, Pilgrim Package.}

\section{PENDAHULUAN}

Wisata pilgrim merupakan jenis wisata yang berkaitan dengan agama, sejarah adat istiadat ataupun kepercayaan. Melalui wisata pilgrim wisatawan banyak mendapatkan pengetahuan mengenai daya tarik yang dikunjungi serta keagaman spiritual. Wisata pilgrim dalam agama Islam yaitu wisata ziarah dan wisata ziarah kubur. Dalam perkembangan pariwisata, aktifitas wisata ziarah ini menyatu dengan kegiatan wisata. Wisata ziarah adalah berkunjung ke tempat suci/ bersejarah seperti kota Makkah, Madinah/ tempat lainnya seperti tempat para ulama yang telah tiada menurut Purwadi (2006:57). Salah satu wisata pilgrim dalam Islam yaitu Ibadah umrah adalah berkunjung ke Ka'bah untuk melakukan serangkaian ibadah dengan syarat-syarat yang telah ditetapkan. Peminat wisata pilgrim saat ini banyak mengalami peningkatan, hal ini dapat dilihat dari banyaknya biro perjalanan wisata yang menjual paket wisata pilgrim. Baik itu biro perjalanan wisata khusus menangani wisata pilgrim maupun biro perjalanan wisata yang menjual paket pilgrim dan paket Tour lainnya.

Salah satu biro perjalanan wisata yang bergerak dalam pelayanan wisata pilgrim di Bali terletak di Kuta yaitu PT. Dongan Sahuta Tour and travel, merupakan biro perjalanan wisata yang berperan dalam memberikan informasi, pelayanan serta berbagai kebutuhan wisatawan yang akan melaksanakan ibadah haji plus ataupun umrah yang melakukan pemberangkatan dari Bali. Berdasarkan pada data yang diperoleh, jumlah jama'ah yang menggunakan paket wisata pilgrim PT. Dongan Sahuta Tour and Travel mengalami fluktuasi selama empat tahun. Bahwa jumlah Jama'ah yang menggunakan paket wisata pilgrim di PT. Dongan Sahuta Tour and Travel mengalami fluktuasi dari tahun ke tahun. Pada tahun 2012 berjumlah 90 orang kemudian meningkat pada tahun 2013 yakni menjadi 120 orang, mengalami penurunan pada tahun 2014 menjadi 90 orang dan meningkat kembali manjadi 100 orang pada tahun 2015. Berdasarkan hasil wawancara dengan Ibu 
Presty selaku karyawan marketing perusahaan diketahui bahwa terjadinya penurunan pada tahun 2014 disebabkan adanya terjadinya kenaikan dolar dan banyaknya bermunculan biro perjalanan wisata yang menangani wisata pilgrim yang muncul pada tahun tersebut. Guna mengupayakan kenaikan pengguna paket wisata pilgrim serta mampu bertahan dalam persaingan antar biro perjalanan wisata yang menjual paket wisata pilgrim, diperlukan strategi pemasaran paket wisata pilgrim yang tepat pada PT. Dongan Sahuta Tour and Travel.

\section{METODE}

Studi dilakukan pada PT. Dongan Sahuta Tour and Travel, yang beralamat di Jl. Majapahit No. 14, Kuta Bali 8036. Adapun indikator yang digunakan untuk pemasaran lingkungan internal adalah, marketing mix 9P, yaitu: (1) product (2) price (3)place (4)promosi (5)physical evidence (6)people (7)process (8)packaging (9)payment menurut (Bryan K. Hukum Fox Collage of Business 2008). Sedangkan pemasaran lingkungan internal indikatornya meliputi: (1)analisis pasar (2)analisis kompetitor (3)analisis pemasok (4)analisis pemerintah (5)analisis teknologi (6)analisis ekonomi. Analisis matriks SWOT digunakan IFAS EFAS untuk mendapatkan strategi pemasaran yang dapat diterapkan oleh perusahaan (Rangkuti 2013:83). Jenis data yang digunakan adalah data kualitatif dan data kuantitatif. Teknik pengumpulan data dilakukan dengan cara wawancara semi terstruktur, observasi, penyebaran kuesioner, studi kepustakaan dan studi dokumentasi. Teknik penentuan sampel dilakukan dengan sampling purposive dan pengambilan sampel lingkungan internal menggunakan pedoman menurut Ferdinan (2005) dalam Subhan (2006:95). Dengan cara mengalikan 17 indikator dengan 5 yang didapatkan jumlah 85 responden untuk internal (jama'ah) sedangkan responden responden eksternal digunakan 30 orang responden. Sedangkan pengambilan sampel lingkungan eksternal dengan ukuran sampel yang layak dalam studi antara 30-500.

\section{HASIL}

PT. Dongan Sahuta Tour and Travel didirikan oleh Bapak Ucok pada tahun 2006, karena banyaknya permintaan konsumen untuk melakukan perjalanan wisata pilgrim ke
Arab Saudi, maka PT. Dongan Sahuta Tour and Travel berinovasi dengan menyediakan paket wisata pilgrim dengan konsep "Deluxe" tidak berarti mahal pada tahun 2012. Dalam suatu perusahaan memiliki suatu lah strategi yang telah dirancang dan dilakukan untuk membentuk serta menyempurnakan usaha dan produk perusahaansehingga dapat memenuhi target laba dan pertumbuhan. Rencana strategi mencakup segmentasi, targeting dan positioning. Strategi pemasaran STP serta marketing mix PT. Dongan Sahuta Tour and Travel. Yang didapatkan dengan menyebarkan kuesioner kepada 85 responden dari lingkungan Internal. Dari segi segmentasi pasar geografis jama'ah yang tertinggi dari Provinsi Jawa Timur sebanyak 43, dari segi Demografis jenis kelamin pria terbanyak yakni 44 orang dengan presentase $52 \%$, dari segi pendidikan terbanyak berpendidikan D3/S1 dengan presentase $55 \%$, dari status pekerjaan wiraswasta tertinggi sebanyak 42 responden dengan nilai presentase $50 \%$. Segmentasi padar dari segmentasi psikografis yaitu jama'ah yang memiliki gaya hidup menengah dan menengah keatas. Sedangkan dari segi segmentasi perilaku dibagi menjadi 3 yaitu 1)intensitas pengguna paket wisata pilgrim $\mathrm{PT}$. Dongan Sahuta Tour and Travel tertinggi dalam nilai presentase $80 \%$ yaitu jama'ah baru pertama kali menggunakan paket wisata pilgrim dari perusahaan. 2)dari segi Informasi yang diperoleh mengenai paket wisata pilgrim PT. Dongan Sahuta Tour and Travel terbanyak 40 jama'ah yang mengetahui informasi tersebut dari teman /saudara. Dari segi Intensitas penggunaan kembali paket wisata pilgrim PT. Dongan Sahuta Tour and Travel yaitu 99\% menyatakan akan menggunakan kembali paket wisata pilgrim yang dimiliki oleh perusahaan. Dari segi segmentasi pasar yang dipilih oleh PT. Dongan Sahuta Tour and Travel yaitu masyarakat muslim dari Pulau Jawa yang tinggal di Bali. Posisi pasar PT. Dongan Sahuta Tour and Travel mengambil pendekatan berdasarkan manfaat (benefit positioning).

PT. Dongan Sahuta Tour and Travel perlu menerapkan strategi yang tepat dalam memasarkan paket wisata pilgrimnya untuk dapat bertahan atau bahkan unggul dalam persaingan dengan travel agent sejenis. Maka diperlukannya analisis lingkungan internal dan eksternal melalui penyebaran kuesioner kepada 85 responden terhadap 17 sub 
indikator lingkungan internal. Dapat dilihat pada Tabel 1 tentang persepsi masing-masing dari sub indikator.

Tabel 1. Hasil Penilaian Lingkungan Internal

\begin{tabular}{|c|c|c|}
\hline No & Indikator & \multirow{2}{*}{$\begin{array}{l}\text { Rata- } \\
\text { rata }\end{array}$} \\
\hline \multicolumn{2}{|r|}{ Kekuatan (Strengh) } & \\
\hline 1 & $\begin{array}{l}\text { Variasi paket wisata pilgrim } \\
\text { (ibadah umrah) yang di } \\
\text { tawarkan. }\end{array}$ & \\
\hline 2 & $\begin{array}{l}\text { Ketepatan waktu dalam } \\
\text { pengantaran dan penjemputan } \\
\text { jama'ah ke dan dari bandara. }\end{array}$ & 3,3 \\
\hline 3 & $\begin{array}{l}\text { Pelayanan hotel restoran dan } \\
\text { transportasi yang digunakan } \\
\text { selama menggunakan paket } \\
\text { wisata pilgrim. }\end{array}$ & 3 \\
\hline 4 & $\begin{array}{l}\text { Kemudahan dalam memperoleh } \\
\text { informasi dan pembelian paket } \\
\text { wisata pilgrim (ibadah umrah) }\end{array}$ & 2,9 \\
\hline 5 & $\begin{array}{l}\text { Keterjangkauan lokasi kantor } \\
\text { PT. Dongan Tour and Travel }\end{array}$ & 2,51 \\
\hline 6 & $\begin{array}{l}\text { Kemampuan berkomunikasi } \\
\text { karyawan dalam memberikan } \\
\text { informasi paket wisata pilgrim } \\
\text { (ibadah umrah) }\end{array}$ & 3,4 \\
\hline 7 & $\begin{array}{l}\text { Kemampuan pengetahuan staff } \\
\text { Muthawif (Guide) mengenai } \\
\text { destinasi wisata yang tercantum } \\
\text { dalam paket wisata pilgrim } \\
\text { (ibadah umrah) }\end{array}$ & 3,2 \\
\hline 8 & $\begin{array}{l}\text { Penanganan keluhan terhadap } \\
\text { paket wisata pilgrim oleh staff } \\
\text { travel dan Muthawif (guide) }\end{array}$ & 3,1 \\
\hline 9 & $\begin{array}{l}\text { Kerapian seragam staff dan } \\
\text { Muthawif (Guide) }\end{array}$ & 3,1 \\
\hline 10 & $\begin{array}{l}\text { Kebersihan } \\
\text { akomodasi dan restoran yang } \\
\text { digunakan selama perjalanan } \\
\text { wisata pilgrim }\end{array}$ & 3,1 \\
\hline 11 & $\begin{array}{l}\text { Kesesuaian acara wisata } \\
\text { (intenerary) yang ditawarkan } \\
\text { dengan pelaksanaan di lapangan }\end{array}$ & 3,2 \\
\hline 12 & $\begin{array}{l}\text { Citra (image) PT. Dongan } \\
\text { Sahuta Tour and Travel sebagai } \\
\text { penyelenggara paket wisata } \\
\text { pilgrim di benak pelanggan }\end{array}$ & 3,4 \\
\hline 13 & $\begin{array}{l}\text { Kelengkapan informasi yang } \\
\text { disediakan oleh perusahaan } \\
\text { mengenai paket wisata pilgrim } \\
\text { pada broshur, website, media } \\
\text { sosial dan lain sebagainya). }\end{array}$ & 3,1 \\
\hline 14 & $\begin{array}{l}\text { Kecepatan dan kemudahan } \\
\text { dalam proses pembayaran paket } \\
\text { wisata pilgrim. }\end{array}$ & 3,5 \\
\hline & Kelemahan (Weakness) & \\
\hline 1 & $\begin{array}{l}\text { Harga paket wisata pilgrim } \\
\text { (ibadah umrah) yang di }\end{array}$ & 2,4 \\
\hline
\end{tabular}

\begin{tabular}{lll}
\hline \multicolumn{4}{l}{ sediakan. } & & \\
\hline 2 & Kegiatan promosi paket wisata & 2,2 \\
& pilgrim yang dilakukan oleh & \\
& perusahaan melalui website, & \\
& media sosial, broshur, E- & \\
& commers dan lain sebagainya. & \\
\hline $3 \quad$ & Design paket wisata pilgrim & 2,4 \\
& yang ditampilkan baik pada & \\
& brosur, website, media sosial \\
& dan lain sebagainya \\
\end{tabular}

Sumber : Hasil Penelitian, 2017.

Pada Tabel 3.1 dari perhitungan skala likert dapat diketahui bahwa indikator lingkungan internal pada faktor kekuatan tertinggi pada indikator kecepatan dan kemudahan dalam proses pembayaran paket wisata dengan nilai rata-rata 3,5 . Sedangkan terendah pada indikator keterjangkauan lokasi kantot PT. Dongan Sahuta Tour and Travel dengan nilai 2,51. Sedangkan faktor kelemahan dengan nilai terendah pada indikator kegiatan promosi paket wisata pilgrim yang dilakukan oleh perusahaan melalui website, media social. Broshur, ECommers dan lain sebagainya dengan nilai 2,2. Sedangkan nilai tertinggi pada indikator design paket wisata pilgrim yang ditampilkan baik pada broshur, website, media sosial dan lain sebagainya. Hasil perhitungan lingkungan eksternal dari perhitungan skala likert terhadap 30 responden dapat dilihat pada Tabel 2 yakni dari para ahli dalam bidang pemasaran.

Tabel 2. Hasil Penilaian Lingkungan Eksternal

\begin{tabular}{llr}
\hline No & \multicolumn{3}{c}{ Indikator } & $\begin{array}{c}\text { Rata- } \\
\text { rata }\end{array}$ \\
\hline 1 & Peluang (Opportunities) & 3,2 \\
& $\begin{array}{l}\text { Jumlah peminat paket wisata } \\
\text { pilgrim (ibadah umrah) yang } \\
\text { meningkat }\end{array}$ & \\
\hline 2 & $\begin{array}{l}\text { Semakin banyaknya BPW/ APW } \\
\text { sebagai Saluran Distribusi. }\end{array}$ & 3,2 \\
\hline 3 & $\begin{array}{l}\text { Kemajuan teknologi dalam } \\
\text { melakukan pemasaran paket } \\
\text { wisata, seperti website, media } \\
\text { sosial, surat elektronik, E- } \\
\text { commerce dan lain-lain. }\end{array}$ \\
\hline 4 & $\begin{array}{l}\text { Tingkat perekonomian } \\
\text { masyarakat Indonesia yang } \\
\text { meningkat }\end{array}$ \\
\hline \multicolumn{4}{c}{ Ancaman (Threats) } \\
\hline 1 & $\begin{array}{l}\text { Semakin banyak online travel } \\
\text { agent yang menjual paket wisata } \\
\text { pilgrim (ibadah umrah) }\end{array}$ \\
\hline 2 & $\begin{array}{l}\text { Keterlibatan birokrasi pemerintah } \\
\text { dalam pengurusan dokumen }\end{array}$ \\
\hline & \multicolumn{1}{c}{2,2} \\
\hline
\end{tabular}




\begin{tabular}{|c|c|c|c|}
\hline \multicolumn{4}{|c|}{ perjalanan } \\
\hline 3 & $\begin{array}{l}\text { Nilai tukar } \\
\text { melemah }\end{array}$ & yang & 1,6 \\
\hline 4 & $\begin{array}{l}\text { Fluktuasi harga } \mathrm{BBM} \\
\text { Bakar Minyak) }\end{array}$ & Bahan & 1,5 \\
\hline
\end{tabular}

Sumber : Hasil Penelitian, 2017.

Pada Tabel 2 dapat ditemukan faktor peluang dan faktor ancaman. Faktor peluang memiliki indikator tertinggi yaitu kemajuan teknologi dalam melakukan pemasaran paket wisata, seperti website, media sosial, surat elektronik dengan nilai rata-rata 3,4. Sedangkan terendah pada indikator tingkat perekonomian masyarakat Indonesia meningkat dengan nilai rata-rata 3,26. Sedangkan faktor ancaman dengan indikator nilai tertinggi pada sub indikator keterlibatan birokrasi pemerintah dalam pengurusan dokumen perjalanan mendapatkan nilai ratarata 2,2. Sedangkan pada nilai terendah yaitu terjadinya fluktuasi harga BBM (Bahan Bakar Minyak).

\section{PEMBAHASAN}

Dapat diketahui dari hasil penyebaran kuesioner terhadap lingkungan internal mendapatkan indikator yaitu faktor kekuatan dan faktor ancaman. Pada faktor kekuatan nilai tertinggi yaitu pada indikator kecepatan dan kemudahan dalam proses pembayaran paket wisata pilgrim dengan nilai 3,5. Hal ini disebabkan perusahaan memberi kemudahan dalam pembayaran paket wisata pilgrim yaitu dengan cara melakukan pembayaran secara bertahap hingga batas maksimal pelunasan yaitu 1 bulan sebelum pemberangkatan jama'ah. Sedangkan nilai terendah pada indikator keterjangkauan lokasi kantor PT. Dongan Sahuta Tour and Travel dengan nilai 2,52. Hal ini dikarenakan bahwa lokasi kantor perusahaan kurang strategis dan kurang mudah di jangkau. Pada Faktor Kelemahan nilai tertinggi pada indikator design paket wisata pilgrim yang ada di media promosi mendapatkan nilai 2,4. Dikarenakan tampilan dari pekat wisata yang kurang menarik di benak jama'ah. Nilai terendah pada indikator kegiatan promosi paket wisata pilgrim yang dilakukan oleh perusahaan mendapatkan nilai 2,2. Hal tersebut disebabkan karena kurang maksimalnya aktifitas yang dilakukan oleh perusahaan dengan kegiatan promosi dalam proses pemasaran.
Sedangkan pada lingkungan eksternal mendapatkan faktor ancaman dan peluang dengan nilai indikator tertinggi yaitu kemajuan teknologi dalam melakukan pemasaran paket wisata, seperti website, media social, surat elektronik, E-commers dan lain-lain mendapatkan nilai 3,4. Hal ini dikarenakan karena kemajuan teknologi dapat membantu kegiatan pemasaran perusahaan. Nilai terendah yaitu 3,2 tingkat perekonomian masyarakat yang meningkat dapat mempengaruhi masyarakat untuk menggunakan paket wisata pilgrim. Pada Indikator ancaman nilai tertinggi yaitu keterlibatan birokrasi pemerintah dalam pengurusan dokumen perjalanan mendapatkan nilai 2,2. Hal ini disebabkan karena kurangnya efektifitas dalam pengurusan dokumen perjalanan. Nilai terendah yaitu terjadinya fluktuasi harga BBM (Bahan Bakar Minyak) dengan nilai 1,5. Harga BBM dapat sangat mempengaruhi harga jual paket wisata kepada pelanggan.

Dari hasil analisis skala likert yang diterapkan kepada faktor lingkungan internal dan faktor lingkungan eksternal akan dimasukkan kedalam matrix SWOT dan mendapatkan strategi pemasaran yang tepat untuk PT. Dongan Sahuta Tour and Travel yaitu :

1. Strategi Strengths Opportunities (SO): strategi penciptaan dan pengembangan produk

2. Strategi Weaknesses Opportunities (WO): strategi promosi

3. Strategi Strengths Threats (ST): strategi pengembangan pasar.

4. Strategi Weaknesses Threats (WT): strategi penetapan harga.

Strategi dan Program yang dapat dilakukan oleh PT. Dongan Sahuta Tour and Travel, yaitu :

1. Strategi Penciptaan dan Pengembangan Produk dengan program sebagai berikut:

a. Menciptakan paket wisata pilgrim yang baru dan up todate.

b. Menciptakan paket pilgrim yang lebih banyak seperti wali pitu, wali lima, wali wolu dan wali songo.

c. Menggunakan akomodasi yang dekat dengan lokasi ibadah.

2. Strategi meningkatkan kegiatan promosi paket wisata pilgrim dengan programprogram sebagai berikut: 
a. Meningkatkan kegiatan promosi melalui media internet.

b. Menciptakan design/ kemasan yang lebih menarik dan inovatif.

c. Memberikan informasi kontak person dan mengenai paket wisata yang terperinci dalam media promosi.

d. Promosi penjualan (sales promotion) yakni melalui sistem networking/ jaringan kemitraan.

e. Memaksimalkan kegiatan promosi perusahaan seperti sering melakukan telemarketing kepada perusahaanperusahaan atau pun perseorangan.

3. Strategi Memperluas Pasar dengan menggunakan program-program :

a. Memperluas pangsa pasar dengan cara publisitas dengan presentasi pada kegiatan yang bersifat keagamaan

b. Memperluas kerjasama dan menjalin hubungan yang baik dengan biro perjalanan wisata dan agen perjalanan wisata baru baik yang ada di Bali maupun luar Bali.

c. Menjalin kerjasama dengan perusahaan-perusahaan yang sering melakukan perjalanan intensif.

d. Melakukan kegiatan pemesanan dari media online/ internet. Seperti website perusahaan/ menggunakan $e$ commerce

e. Menjaga hubungan baik dengan pelangan dan pemasok biro perjalanan wisata baru.

4. Strategi Penetapan Harga dapat dilakukan dengan menggunakan program-program sebagai berikut :

a. Memberikan kemudahan dalam proses pembayaran produk yang dimiliki oleh perusahaan

b. Penetapan harga paket wisata pilgrim dengan atau tanpa jasa pengurusan dokumen perjalanan

c. Meningkatkan Trade discount kepada Agen Perjalanan Wisata atau Biro Perjalanan Wisata yang memberikan kontribusi sangat besar terhadap penjualan produk perusahaan.

\section{SIMPULAN DAN SARAN Simpulan}

Strategi yang telah dilakukan oleh PT. Dongan Sahuta Tour and Travel memasarkan produknya kepada pasar yakni wisatawan yang beragama Islam dan berasal dari Jawa Timur,
Bali, Jawa Tengah, Jawa Barat serta masyarakat dari berbagai pulau yang tinggal di Bali. Kegiatan pemasaran yang dilakukan selama ini dengan memperkuat citra perusahaan supaya jama'ah dapat mempercayakan kembali perjalanannya kepada PT. Dongan Sahuta Tour and Travel. Strategi pemasaran berikutnya yang telah dilakukan oleh perusahaan yaitu dengan melakukan telemarketing ke perkantoran, melakukan presentasi produk dalam perkumpulan pengajian, pemasaran melalui website perusahaan dan media sosial. Menjalin kerjasama dengan agen-agen serta biro perjalanan wisata yang dapat membantu menaikkan volume jama'ah.

Strategi dan program pemasaran paket wisata pilgrim yang dapat diterapkan oleh PT. Dongan Sahuta Tour and Travel adalah: Menciptakan dan pengembangan produk wisata yang berkualitas. Mempertahankan serta meningkatkan kualitas akomodasi, pelayanan dan citra perusahaan dibenak pelanggan dan jama'ah. Menciptakan dan meningkatkan hubungan baik dengan pelanggan. Mengoptimalkan sistem booking online seperti menggunakan E-commers, mengelola website perusahaan secara berkala. Memaksimalkan kegiatan promosi paket wisata pilgrim melalui media sosial, cetak maupun internet. Mempererat kerjasama dengan pemasok (saluran distribusi) baru. Menciptakan design yang lebih menarik dalam media promosi. Memberikan informasi yang lebih terperinci pada media promosi. Memperluas kerjasama dengan agen-agen perjalanan. Menjalin kerjasama dengan pemerintah. Memberikan kemudahan dalam proses pembayaran produk yang dimiliki oleh perusahaan. Strategi penetapan harga paket wisata pilgrim yang terjangkau.

\section{Saran}

1. Melakukan strategi penetapan harga yang terjangkau dengan menyertakan pelayanan pengurusan dokumen perjalanan.

2. Memperluas pangsa pasar dengan memasarkan paket pilgrim melalui saluran distribusi langsung atau tanpa perantara.

3. Menyediakan Survey kepuasan pelanggan.

4. Meningkatkan kegiatan promosi yang lebih aktif, seperti menjalin kerjasama dengan media cetak, majalah islam yang ada di Bali. 


\section{DAFTAR PUSTAKA}

Becherel, Lionel., Vellas, Francois. 2008. Pemasaran Pariwisata Internasional. Jakarta: Yayasan Obor Indonesia.

Bungin, Burhan. 2010. Metodologi Penelitian Kuantitatif. Jakarta: Kencana.

Chan Gladish, 2012, The 9 Ps in Marketing Mix.

Purwadi, dkk. 2006. Jejak Para Wali dan Ziarah Spiritual. Jakarta: Kompas.

Rangkuti, Freddy. 1997. Analisis Swot Teknik Membedah Kasus Bisnis: Cara Perhitungan Bobot, Rating dan OCAI.
Cetakan ke-17 2013. Jakarta: PT. Gramedia Pustaka Utama.

Sugiyono. 2014. Metode penelitian Kuantitatif Kualitatif dan R\&D. Bandung : ALFABETA.

Timothy, Dallen, J. Oslen, Daniel, H. 2006. Tourism, Religion \& Spiritual Journeys. Oxon: Routledge.

Tjiptono, Fandy. 1997. Strategi Pemasaran. Edisi kedua. Yogyakarta: ANDI Yogyakarta.

Yoeti. Oka. A. 2003. Tours and Travel Marketing. Jakarta: PT. Perca. 